\title{
Quantitative Research Methods Training in Education Leadership and Administration Preparation Programs as Disciplined Inquiry for Building School Improvement Capacity
}

\author{
Alex J. Bowers \\ Teachers College, Columbia University
}

\begin{abstract}
:
The quantitative research methods course is a staple of graduate programs in education leadership and administration. Historically, these courses serve to train aspiring district and school leaders in fundamental statistical research topics. This article argues for programs to focus as well in these courses on helping aspiring leaders develop skills as practitioner-scholars, including deepening their practice around data analytics, providing opportunities to read and evaluate peer-reviewed research, analyzing data using current methods, and applying findings to facilitate building evidence-based improvement cycles in their schools. Additional data leadership training should be offered for the practicing administrator, educational quantitative analyst, research specialist and district data scientist.
\end{abstract}

KEYWORDS: Quantitative Methods, Statistical Analysis, Educational Administration, School Administration, Leadership, College Programs, Doctoral Programs, Graduate Study, Methods Courses, Methods Research, Data Analytics, Data Science, Design-based research, Continuous Improvement

\section{Introduction:}

I believe that the greatest impact of the quantitative approach will not be in the area of problem solving, although it will have growing usefulness there. Its greatest impact will be on problem formulation: the way managers think about their problems - how they size them up, bring new insights to bear on them, relate them to other problems, communicate with other people about them, and gather information for analyzing them. In this sense, the results that "quantitative people" have produced are beginning to contribute to in a really significant way to the art of management (Farmer, 1970, p.21).

\footnotetext{
${ }^{1}$ This document is a pre-print of this manuscript, published in the Journal of Research on Leadership Education. Citation: Bowers, A.J. (2017) Quantitative Research Methods Training in Education Leadership and Administration Preparation Programs as Disciplined Inquiry for Building School Improvement Capacity. Journal of Research on Leadership Education, 12(1), p.72-96. http://doi.org/10.1177/1942775116659462

${ }^{2}$ Alex J. Bowers (bowers@ @c.edu); Teachers College, Columbia University; Bowers@tc.edu; 525 W. 120th Street, New York, New York 10027. ORCiD: 0000-0002-5140-6428
}

Bowers, A.J. (2017)
The purpose of this article is to provide a discussion of the use of quantitative research methods instruction in university graduate programs of education leadership and administration, with a specific focus on training doctoral students in Ed.D and Ph.D degree programs as practitioner-scholars who aim to work as district leader practitioners. These programs have historically included methods training for practitioner-scholars aspiring to hold administrative positions in K-12 schooling organizations with an Ed.D or Ph.D degree, with many graduates becoming school district central office staff, superintendents, or state or national policymakers. A quantitative research methods course has a longstanding tradition of being included within education leadership graduate programs (Anderson \& Reynolds, 2015; Hess \& Kelly, 2005; Militello, Gajda, \& Bowers, 2009; Thornton \& Perreault, 2002), along with a host of other courses in programs designed to help graduates learn to lead schools and districts, courses such as qualitative methods, diversity and social justice issues, law, policy, finance and budgeting, human resource management, facilities, labor negotiation, curriculum and instruction, assessment and evaluation, ethics, and the list goes on. Over the past few decades, programs focused on doctoral training in education leadership are on the rise, with continually increasing numbers of programs and graduates in the U.S. (B. D. Baker, Orr, \& Young, 2007; Goldring \& Schuermann, 2009; Hackmann \& McCarthy, 2011).

However, over the same time period there has been a host of critiques of education leadership preparation, with increasing attention on the Ed.D. as a problematic degree and training structure for preparing graduates to actually lead schools and districts well (Goldring \& Schuermann, 2009; Perry, 2012; Shulman, Golde, Bueschel, \& Garabedian, 2006). Nevertheless, throughout this context the quantitative research methods course remains. It is within this context that I aim to consider the following questions as a means to help engage students, preparation programs, district and state school administrators, and university faculty in examining the quantitative research methods course. These questions include: What are quantitative research methods courses in education leadership? What is the purpose of such courses? Why are they included? What are the expectations for student outcomes, especially as applied to their work on the ground in districts? And what are some useful structures, curricula, and instructional techniques for these types of courses that can prepare practitioner-scholars to use data and research in their everyday practice to help motivate instructional improvement in their organizations? 
In this article, I first overview the current conversation in the research literature on the delivery of graduate programs in education leadership, such as the $\mathrm{EdD}$ and $\mathrm{PhD}$, aimed at training scholar-practitioners to take leadership positions in schools and districts. Second, I discuss the purpose of the quantitative methods course in these types of programs of study, an issue rarely discussed in the research literature. Third, I then turn to discussing specifics of how to provide professional capacity building through graduate programs through opportunities to discuss and apply current research, engage in meaningful analysis and critique of data in schools, and provide opportunities for increased collaboration between universities and districts. Throughout, my contention here for quantitative methods courses in education leadership preparation programs is that while it is important to provide instruction on basic statistics and empirical reasoning through structured testing using quantitative methods, quantitative methods courses provide an opportunity to build the capacity of school leaders as practitioner-scholars in assessment literacy, data literacy, and how to facilitate and lead building professional capacity through evidence-based improvement cycles.

\section{Preparing Administrators to Lead Schooling Organizations:}

Traditionally in the preparation of school district administration and leadership, the quantitative research methods course has been one of many courses designed to help the school system leader learn the skills needed to effectively manage systems of schools (Bruno \& Fox, 1973; Kowalski, McCord, Peterson, Young, \& Ellerson, 2011). More recently, as research has shown the effect that central office district administrators and the superintendent can have on schooling outcomes, such as growth in student achievement, the professional development of principals and the central office, and the influence over school facilities and community involvement (Bird, Dunaway, Hancock, \& Wang, 2013; Bowers, 2008, 2010b, 2015; Bowers \& Chen, 2015; Bowers \& Lee, 2013; Honig, 2003, 2008, 2009, 2012; Wallace Foundation, 2013), preparation programs have included the areas of instructional improvement, adult development, and continuous systems improvement, among others (Bryk, Gomez, \& Grunow, 2011; Carter, Glass, \& Hord, 1993; Drago-Severson \& Blum-DeStefano, 2013). Across these types of programs, graduates have historically rated their experiences as preparing them "well" or "very well" for central office and superintendent roles (Kowalski, et al., 2011). As an example, the American Association of School Administrators (AASA) has conducted over 40 years of extensive surveys of superintendents from across the US, asking them a variety of questions about the job every ten years, including their perceptions of how well they were trained (Knezevich, 1971; Kowalski, et al., 2011).

As a recent example of the positive perception of superintendent training, when asked to rate their overall perception of their academic training program, $78.5 \%$ of respondents replied that their training was either "good" or "excellent", mirroring other similar studies (Kowalski, et al., 2011). Additionally, from the 2000 to 2010 AASA study, while there was significant growth of Bowers, A.J. (2017) the number of preparation programs and the overall number of graduates with $\mathrm{EdDs}$ and $\mathrm{PhDs}$ from these programs, superintendent responses to rating the credibility of their professors as "good" or "excellent" rose from $65.9 \%$ in 2000 to $81.1 \%$ in 2010 (Kowalski, et al., 2011). In relation to the importance of specific courses in their preparation programs to the job of the superintendent, the majority of superintendent respondents have continually rated school law, finance, public relations and human resource management as "extremely important". However, interestingly in relation to the topic of the discussion in this article, the courses receiving the most responses for "unimportant" for superintendents are organizational theory, tests and measurements, research, and diversity.

Thus, these findings, from the people who actually do the job of district administration, present an interesting conundrum given the recent research literature on the $\mathrm{EdD}$ and $\mathrm{PhD}$ in education leadership. Superintendents continually rate their university training programs highly, yet there is a deep line of criticism in the research literature of the focus, quality, and rigor of doctoral programs in education leadership, in which these critiques focus on the extent to which programs can prepare leaders for actual practice in schools and districts (Goldring \& Schuermann, 2009). In recent years, there have been multiple reports that have critiqued the extent to which university preparation programs train leaders for the job of running school districts (Grogan \& Andrews, 2002; Levine, 2005; Shulman, et al., 2006), especially when it comes to the use of the EdD as the central capstone of a practitioner degree - a degree which historically has taken the form of a research dissertation (Townsend, 2002). This critique also has extended to the $\mathrm{PhD}$ in the same and similar programs, as there has historically been little difference between the two degrees in practice, with aspiring researchers and practitioners obtaining either degree, with the only difference in requirements being an advanced statistics course for the PhD (McCarthy \& Forsyth, 2009; Osguthorpe \& Wong, 1993).

Despite the positive responses of superintendents to their past university training programs, to address these critiques from the research literature many university programs have recently engaged in redesigns (Sanzo \& Scribner, 2015; Smrekar \& McGraner, 2009), refocusing their doctoral training programs on the issues and the problems of practice that are of most concern to their students in their daily work in schools (Carnegie Project on the Education Doctorate, n.d.; Goldring \& Schuermann, 2009; Shulman, et al., 2006). This refocusing is meant in part to make the training more meaningful and relevant for practice in districts. The vast majority of graduate students in these programs are full time school practitioners who are steeped in the everyday issues of schooling systems. A "problems of practice" perspective is meant to engage practitioners in action research (Herr \& Anderson, 2015) in which graduate students take on these issues that are most relevant for their context as a means to engage both the graduate student and the organization to be studied in working to solve real-world problems in schools (Coburn, Penuel, \& Geil, 2013). This thus addresses one of the 
central critiques from the literature on the EdD on relevance of the preparation program to practice.

However, despite the current popularity of a problems of practice approach, there is a long-standing counter argument. Published in the very first volume and issue of Educational Administration Quarterly in 1965, Hills noted a central issue with problems of practice when it comes to training future leaders of schools:

This is emphatically not to say that practical problems are not important, nor even that they are less important than some other kinds of problems. But it is to say that a problem centered approach to the study and practice of administration, regardless of how scientific, obscures and possibly precludes the recognition of a further, and to me, equally significant kind of relevance...The tiedto-action quality of current approaches to the study and practice of administration, even those which wholeheartedly embrace the social sciences, rules out the possibility of developing in students and practitioners what Berger has called the "sociological consciousness" or "intellectual irreverence". p.23-24 (Hills, 1965).

In this quote and article, Hills outlines the point that a problems of practice approach limits the student to attempting to solve the everyday problems of a system that itself may be in need of rethinking. To the point, Hills notes that "the distinctive characteristic of the action-oriented - the applied science approach is that the goal is always given" (p.25). Thus, a goal of university programs should be "that administrators in particular should be aware of the fact that other worlds besides their own do exist, that there are alternatives" (p.27). While written over 50 years ago, Hills' points have a certain salience today, especially when considered within the context of current social justice critiques of the education system and education leadership specifically (Brooks, 2012; Davis, Gooden, \& Bowers, 2015; Horsford, 2010; Reyes \& Wagstaff, 2005), a system for which Hills might argue a problems of practice approach might help prop up rather than rethink, restructure and reform.

To sum up these points, to rely on yet another nearly 50 year old article on these issues, Cunningham and Nystrand (1969) could easily be talking about contemporary issues of administrator preparation when they noted:

Although we now perceive the administrator as an applied social scientist and urge students to become capable students of behavioral science, we have not put aside altogether the images of educational superman, technical expert, and democratic leader. We have developed instead a very crowded curriculum which, in too many cases, conveys a composite image of the administrator who is all-knowing, well-versed in all details of administering schools, and able to use behavioral science "principles"... p.10 (Cunningham \& Nystrand, 1969)
Thus, graduate students in education leadership today enter into a field of university training programs simultaneously seen as a positive stepping stone into the profession yet also under critique and revision in an effort to make the student's investment of time and money in their training relevant, rigorous, applied, and research-based. As with the majority of the sub-domains within educational leadership research and practice (Oplatka, 2009; Wang \& Bowers, 2016; Wang, Bowers, \& Fikis, 2015), the history of professional preparation of school leaders in university programs could be termed, as Riehl has recently termed the research in educational leadership overall, as "mostly unpunctuated disequilibrium" (Riehl, 2015). It is within this context that I aim to discuss the issue of quantitative methods in education leadership preparation programs, especially as they relate to training doctoral students as scholar-practitioners who aim to work as district leader practitioners.

\section{Why Teach Quantitative Research Methods to Aspiring District Leaders?}

Why do we teach quantitative methods in programs that are aimed to train working practitioners for roles in school and district organizational leadership? Historically, it has been a taken for granted course in university programs. But why include it among all of the other possible courses that vie for attention to help prepare students? As noted above, superintendents rate research methods and data and assessment courses as some of the least useful. Additionally, it is wellknown that while school leaders will often justify decisions in schools through using the phrase "research says" as well as refer obliquely to vague research topics such as "brain science", studies show that school leaders rarely read current education research, nor do they incorporate specific research findings into their practice, and even rarer still do they do primary research in their schools (Fusarelli, 2008). Nevertheless, over the last 50 years, and especially the first decade and a half of the $21^{\text {st }}$ century, there has been an ever increasing positive research literature publication trend of ever more high quality education research, from across ideological, methodological and epistemological domains (Wang \& Bowers, 2016; Wang, et al., 2015). Specifically for quantitative methods, as recently noted by Guthrie (2009) in relation to discussing the EdD in education leadership:

Modern education research increasingly is characterized by a rigorous methodological and philosophical paradigm entirely different than was true even in the late 20th century. Experimentation and large data set analyses, random and fixed effect modeling, are now the expected research mode. Measurement techniques such as those regularly used by epidemiologists, psychologists, and economists, regression and discontinuity regression analysis, propensity analysis, and hierarchical linear modeling are increasingly threshold quantitative skills for research methodological competency. These are skill sets and understandings that take time to impart, require immersion in analyses and research to perfect, and are not learned by lecture and from textbooks alone. p.3-4 (Guthrie, 2009) 
In addition to the growing diversity of quantitative methods aimed to capture and model the complex sociological interactions in schools (Goff \& Finch, 2015; Hallinger \& Heck, 2011), a search of the ERIC.gov education research search engine shows that for the 2014 year alone, there were over 20,000 articles that mentioned "leadership" or "administration", with almost 3,000 of these mentioning "statistical analysis" as a keyword. So what is the aspiring scholar-practitioner to do? Is it possible to keep up with 20,000 articles or even 3,000 , while holding jobs in schools that require many more than 40 hours a week? If we have reserved the time and space in a busy and crowded university training program for quantitative research methods, how should we use that time to best meet the needs of the students, their organizations, the program and the research literature?

This question of the point of quantitative research methods programming has rarely been taken up in the education leadership research literature. One of the few attempts to overview the purpose of quantitative research methods courses in education leadership graduate programs, as well as differences and innovations across programs, was an effort by Bruno and Fox in 1973 in a report commissioned by the University Council for Educational Administration (UCEA) titled appropriately enough Quantitative Analysis in Educational Administrator Preparation Programs (Bruno \& Fox, 1973). In their extensive report, Bruno and Fox reviewed the literature at the time on the use of quantitative methods in education administration and management programs, and how the methods courses could help aspiring school administrators address the needs of the rising dual demands of accountability and instructional improvement. Additionally, they provided overviews of the content of multiple university programs, providing evidence that has not been updated in the 40 years since. Indeed, a main recommendation of the present paper is to encourage UCEA or other like-minded institutions or researchers to provide evidence from programs in a similar manner. In the following quote, Bruno and Fox (1973) summarize well the position of programs on the purpose of quantitative methods courses in graduate education administrator programs both then and currently:

It is important to emphasize that programs constructed for the practicing decision-maker should not be designed to make him an expert in the use of the various technical tools and concepts that are involved. Rather, these programs should be designed to acquaint him with what tools and concepts are available, under what situations they can be used, and, most importantly, what their limitations are. It is possible that most program analyses will be performed by central office staff or outside consultants. Other district personnel should know what this group can do and be able to interpret and apply the results of such analyses. Moreover, all decision-makers should be able to apply analytical thinking to the decisions they must make daily. In brief, general administrators should be trained to criticize and utilize analyses, rather than formulate them themselves. p.24-25 (Bruno \& Fox, 1973)
While obviously dated in their pronoun use, this quote from Bruno and Fox exemplifies the central argument of the present article - quantitative research methods courses in education leadership preparation programs should teach the practicing decision maker how to apply analytical thinking, formulate evidence-based questions, and criticize and utilize analyses. Given the vast quantity of research published annually, combined with the ever increasing sophistication of research methods, including quantitative, qualitative, and mixed methods, a central purpose of leadership training is to train future school system leaders to become consumers of this work and apply critical thinking and evaluation of analytics to their decisions in their schools on a daily basis.

Contemporary authors have worked to detail specifics of what aspects of quantitative analysis may be the most useful for practitioners to be fluent in, specifically assessment literacy and data literacy. The term "fluent" here is purposeful, as much of this literature uses the term "literacy" to evoke the idea of the ability to read, unpack and summarize research and apply critical thinking and questioning of that research to practice. First, assessment literacy (Boudett, City, \& Murnane, 2013; Popham, $2009,2010)$ includes a working knowledge of assessment and evaluation. Given the increasing demands of accountability in schools and the use of standardized assessments, research on assessment literacy has shown that a key component of preparation programs should be to instill an ability in their graduates to critique assessments and evaluations, know what to look for when examining content, criterion and construct validity arguments, and understand how to help teachers assess both student growth and the teacher's own development in valid and reliable ways. This type of knowledge can change the stance of administrators towards assessments from compliance to useful feedback on student, teacher, school and organizational performance, measured in many different ways beyond test scores for formative and summative feedback (Halverson, 2010; Leithwood, 2013). Second, data literacy (Jacobs, Gregory, Hoppey, \& Yendol-Hoppey, 2009; Mandinach, Friedman, \& Gummer, 2015; Mandinach \& Gummer, 2013) includes the concepts of knowing how to identify and collect relevant data that can then be turned to analysis to help test hypotheses and questions to help decide on and then monitor and iterate on decisions and courses of action (Bowers, Shoho, \& Barnett, 2014). More specific than data driven decision making (Wayman \& Stringfield, 2006), data literacy focuses on the tasks and skills needed to organize and understand the information flow in schooling organizations, and how to prioritize and analyze data to help inform current decisions and evidence-based improvement cycles (Bowers, 2008; Bowers, Krumm, Feng, \& Podkul, 2016; Bryk, et al., 2011; Cho \& Wayman, 2015; Feng, Krumm, Bowers, \& Podkul, 2016; Marsh, 2012; Schildkamp, Poortman, \& Handelzalts, 2016; Wayman, Cho, Jimerson, \& Snodgrass Rangel, 2015).

Moreover, when it comes to the quantitatively-oriented questions of practitioners in schools, recent research has shown that the data and analysis needs of the system differ at the

Bowers, A.J. (2017) 
teacher, principal and superintendent levels (Brocato, Willis, \& Dechert, 2014; Corcoran, Peck, \& Reitzug, 2013; Cosner, 2014; Farley-Ripple \& Cho, 2014). The evidence from this work can help form a basis for creating conversations around the data and analytic needs of graduate students in education leadership doctoral programs and their current and future organizations. For example, Brocato, Willis and Dechert (2014) asked a large sample of districts in a state to have superintendents, principals and teachers respond to the prompt: "what components of a statewide longitudinal data system are needed for that system to best meet the respective needs of superintendent, principal and teacher leaders?" Interestingly, their results showed that each organizational level responded with very different needs in which teachers focused on individual student demographic, performance and growth needs, principals focused on teacher evaluation and hiring, and superintendents focused on comparative data (comparing student, teacher and school growth over time) as well as budgets and community relations. The responses point to three main issues. First, different stakeholders have different data needs (Bernhardt, 2013). Thus, any recommendations for encouraging data use must incorporate these differing perspectives. Second, while all of the respondents wished for data that would inform decisions on specific people, such as students or teachers, all of the respondents indicated that comparisons were very important. This points to the need for analysis, especially correlations, cross-tabs, and scatterplots as an accessible means to make comparisons. Third, the results relate to the large variety of data and analysis needs throughout each level of a schooling system, which highlights the need for graduate instruction in how to select the "data story" among the large variety of choices, as a means to focus the development of assessment and data literacy skills within a school or district as a means to build capacity for instructional improvement (Bambrick-Santoyo, 2010; Bernhardt, 2013; Boudett, et al., 2013; Cosner, 2014; Marsh, 2012; Marsh, Bertrand, \& Huguet, 2015; Piety, 2013).

As an example from my own courses, in addition to the interesting results of their study, the question asked by Brocato, Willis and Dechert (2014) can be very useful to start a discussion in a quantitative methods course or in engaging school leaders in discussions about their data, helping to structure conversations around issues of assessment literacy, data literacy and data driven decision making. I have found that school leaders will dig deeply into the main issues when I use the following protocol: 1) ask the Brocato, Willis and Dechert (2014) question, but ask participants to first write down their responses as if they were a teacher in their own organization, then repeat for the principal, and then the superintendent; 2) have participants form groups of two to three and have them discuss their answers; 3 ) then ask them to draw a Venn diagram, with one circle each for the three different levels; 4) discuss where the overlaps are and where they are not and ask why; 5) then review their answers in light of the answers from the study itself and provide time to discuss the differences and what they might mean for how to understand the data and assessment needs of a district. This type of discussion protocol in a course or professional development opportunity provides an excellent Bowers, A.J. (2017) opportunity for practitioners to begin to unpack the differences in data needs across an organization. For students in doctoral programs in education leadership who most likely are teachers or school building administrators, this type of discussion encourages them to consider the data perspectives of each of the levels in the system, and how those may differ, and then to consider why they differ. For the practitioner-scholar in a graduate quantitative methods course, using data encounter and discussion protocols such as this creates a space in the course and curriculum for the expression of their current data needs around their problems of practice while structuring these discussions through opening up the conversations to consider the broader needs across organizations. The questions and issues raised by students and instructors through this type of dialogue can then be incorporated into course discussions, assignments, or as a start in developing action research questions.

Given the large efforts of the work of educators over the last 50 years to generate and record ever increasing streams of data in schools, in addition to assessment and data literacy, a central professional development need of educators is now in turning to building their capacity around data use to inform evidence-based improvement cycles in their organizations (Bowers, et al., 2014). As has been noted in the recent literature on evidence-based improvement cycles in schools, schooling organizations should strive to build trusting and robust cultures around evidence and data use for everyone within the system (Boudett, et al., 2013; Schildkamp \& Poortman, 2015; Schildkamp, Poortman, \& Handelzalts, 2015). When done well, any teacher should be able to ask any other teacher, principal or central office staff "what is your evidence for that statement?", and this question should be interpreted by a colleague as a trusting and helpful question which is aimed at helping the entire organization improve (Boudett, et al., 2013; Bryk, et al., 2011). Note also that this changes the orientation of the school organization, from one of low evidence/high inference, to high evidence/low inference, addressing the problems of above such as the use of the phrase "research says", instead focusing a school on examining the evidence (Bowers, et al., 2014). As part of my argument here in this article, quantitative methods courses should go beyond the notion of action research focusing on addressing a specific problem of practice for a student's organization, and include an opportunity for students to develop the skills on how to lead evidence-based improvement cycles, also termed plan-do-studyact cycles.

Thus, throughout this article I argue for a more applied focus for the quantitative research methods course. Nevertheless, the fundamentals of statistics methods and research are important considerations to include within these types of courses, especially when it comes to interpretation and application. As an example, a component of the data literacy and assessment literacy domains (Mandinach \& Gummer, 2016; Popham, 2010) is providing students with an understanding of sampling distributions, especially when it comes to interpreting t-tests, ANOVAs, and correlations (Cohen, Cohen, West, \& Aiken, 2003), but also in building capacity around discussing both averages, the variation around those averages (DeAngelis \& 
Ayers, 2009) as a means to discuss the context and comparability across analysis samples in schools and districts. Providing a robust discussion of the fundamental assumptions and interpretations of foundational statistics should be an aspect embedded within the quantitative methods course, as a firm understanding of the distributional assumptions of statistics can help prevent students mis-interpreting their results, such as appropriately interpreting p-values versus effect sizes, as well as providing a robust discussion of what has been called "statistical fishing", "p-hacking", and the "garden of forking paths" (Gelman \& Loken, 2013). My point here is not that these are separate issues from those from above, but rather that not only do the domains of data literacy and assessment literacy begin to address these issues, but also this type of training provides the practitioner-scholar with training that addresses the critique from the Bruno \& Fox (1973) to train school leaders around knowing what concepts and tools are available, when and where to apply them, and what the limitations may be.

\section{Quantitative Methods as Disciplined Inquiry for Building School Improvement Capacity}

My argument thus is that the quantitative research methods perspective that I've articulated here can serve as a means to build evidence-based improvement cycles for schools in a university's community, extending beyond an education leadership course program in an attempt to deepen and enrich the relationship between universities, their graduates, and the schools and districts in which they serve. In this section I outline a three part strategy: 1) pivoting the quantitative research methods course to focus on how to build capacity for improvement cycles in schools, 2) providing structured yet informal opportunities for graduate students and faculty to discuss, evaluate and apply recent peer-reviewed research to their own research questions through the use of research journal clubs, and 3) working to build strong university-district partnerships to help improve capacity within and between the organizations through a networked improvement community. Throughout this strategy, while I argue from the perspective of quantitative courses offered specifically in education leadership programs, I acknowledge that currently many graduate schools of education only offer quantitative courses college-wide, open and required of all students across a college of education. Given that graduates across a school of education will have advanced degrees in their specialties, and thus most likely will be expected to take on some form of a leadership role in their districts given this training, I argue that these strategies should also be considered as applicable for the college-wide quantitative methods course.

The first strategy focuses on quantitative methods courses in education leadership programs becoming much more than teaching basic descriptive statistics. These courses are an opportunity, and at times the only opportunity, for graduate students to encounter not only the ideas on how to test empirical questions with statistics, but also how to build capacity around research evidence and data as a means to build trust in schools and help to develop the talent of their school faculty through evidence-based improvement cycles. As an example from my

Bowers, A.J. (2017) own quantitative methods courses, which I have taught for over a decade in colleges of education, I use a three section syllabus with roughly equal time devoted throughout a semester to: 1) how to read and critique peer reviewed research literature; 2) descriptive inferential statistics including t-tests, ANOVA, correlation and regression; and 3) evidence-based improvement cycles. In the first third of the class, I facilitate students encountering peer-reviewed research. This section also includes the assessment literacy issues of validity and reliability (Popham, 2010), as these apply directly to internal and external validity of research studies (McEwan \& McEwan, 2003). Students read and critique primary research articles on issues of validity and reliability, selecting recent articles from the literature that address relevant issues from their organizations (McEwan \& McEwan, 2003; Schreiber \& Asner-Self, 2011), such as the evidence for program effects from the US What Works Clearinghouse (WWC) (US Department of Education, n.d.). As an example of the structure and flow of this work from my own courses, for a student interested in helping her teachers improve literacy instruction for English language learners, she first searched the WWC for intervention reports, and found one that matched similar instructional methods for her school (WWC, 2006) in which teachers use instructional conversations and literature logs to improve literacy instruction. The student in the class then applied her new knowledge from this section of the course on how to critique the internal and external validity of research studies to an evaluation of one of the studies reviewed by the WWC (Saunders, 1999). In a 3-5 page research study critique, she discussed the sample size, the quasi-experimental method used to test the intervention, and then based on her evaluation of the internal validity of the study, linked the extent to which the study had external validity to her issues of leading instructional improvement in her school through possibly incorporating these techniques given her informed critique of the validity and reliability of the study. As just one example, this type of section and assignment opens the doors for practitionerscholars to begin to unpack and take ownership of their own informed evaluation of research, assessing the veracity of the claims in peer-reviewed research themselves using current tools available, and linking that work to issues in their own practice.

In the second section of the course, students then use these articles as the basis for a literature review (Boote \& Beile, 2005) that motivates an analysis of relevant data from their own organization. They are tasked with searching out the data analyst in their organization who has the information they need or using state public information, and then use descriptive statistics to address their own research questions. The central concepts for application to their data include examining the mean and variance in their data along with including error bars on bar graphs as the students then must confront the issue of noise and variance in their data (rather than depend exclusively on the average), sample size, and the problems with statistical significance (DeAngelis \& Ayers, 2009). This provides a foundation for the use of chi-square and a variety of t-tests and ANOVA. Additional topics include correlations and univariate regression, along with the power of displaying multiple dimensions of data through scatterplots. Just as importantly, 
instruction also includes issues of honest graphical reporting of statistics, such as ensuring that the y-axis on a bar graph goes from the minimum to the maximum, such as from 0 to 100 for percentage scales, showing the truth in the data (Bernhardt, 2013; Huff \& Geis, 1954; Tufte, 2001). This is especially important as a means to move practitioners away from pie charts and the current era of "infovis", "chart-junk" and low information graphic design meant to advertise and convince rather than provide honest data reporting (Tufte, 2001). In the final section of the course, students read the current literature on implementing evidence-based improvement cycles in their schools (Boudett, et al., 2013), and build what I call "data action plans" based on their literature review and data analysis from earlier in the semester, which could serve as the basis for beginning a conversation in their own organization on evidencebased improvement. Throughout the course, analysis is done in Microsoft Excel, as the program is able to handle a wide range of analyses (de Levie, 2012), has fairly straight forward plotting capabilities, and is usually available in students' organizations.

Continuing with the example of the student above in examining literacy instruction in her school, she first translated the individual article critique into a larger literature review, then provided an analysis of the public data on literacy instruction in her district, and built her data action plan from this information to provide a pilot evaluation of the current literacy instruction in her school. In translating the article critique into a larger literature review, the student used current literature search engines (such as ERIC.gov, JSTOR, and Google Scholar) to find articles related to her first article, topic and the WWC report. Following the recommendations for literature reviews in doctoral education programs of this type (Boote \& Beile, 2005), the student then built a structured ten page literature review that included over thirty articles, reviewing the major strands of research in the area of literacy instruction for English language learners, reviewing the current state of the field through validity and reliability lens as well as linking the findings across the studies to the student's own future work in her schools. This type of writing helps students to begin to build the foundation for the much larger review of literature for their dissertations, provides an opportunity for students to encounter the current research and methods in the field, both quantitative and qualitative, and facilitates their learning on how to organize that research to help motivate analyses of the data in their own schools, both within their graduate program and for later in their careers in schools and districts. This student then proceeded to use this literature review to formulate research questions for a data analysis study, in which she examined the numbers from her state's education agency on her district's schools, and applied chi-square, single-sample t-tests, ANOVA and correlations to test the extent to which her district's schools were serving English language learners well. Chi-square provided a means to examine the extent that each school had similar proportions of ELL students, she used a single-sample t-test to examine the extent to which her district's ELL students significantly scored above or below state averages on the standardized tests, ANOVA was used in a similar way to examine the extent of differences between the schools, the

Bowers, A.J. (2017) district, the region and the state, and then she provided correlations and scatterplots to show the relationship of literacy to other outcomes across the state, such as mathematics, graduation, etc. In the final section of the course, the student then built a data action plan from this previous work using a logic model and evaluation framework from the course readings (Bambrick-Santoyo, 2010; Boudett, et al., 2013; Schreiber \& Asner-Self, 2011) that provided a potential path forward in studying her district's recent literacy instruction reforms. This data action plan included examining the research literature around the district's new literacy initiative and applying the validity and reliability concerns from that work to the issues of implementation in the district, identifying the major stakeholders in the improvement process, then articulating a plan-do-studyact continuous improvement cycle for the district, collecting the types of data that would be needed to assess progress, and then how to follow-up, assess and engage in the next round of questions and evaluation procedures. In the final section of this process, the students consider the multiple problems and challenges they may face in attempting to implement such a plan, given the current research and their assessment of the political environment in their school. In this way, the course provides a means for students to learn the foundations of quantitative research application, gives them ownership of a project that facilitates their learning on how to pose and then address data-informed questions and evidence-based improvement cycles, and provides an opportunity to articulate how they would go about such a process. This helps the graduate student begin to formulate what could become the foundation for their dissertation study.

Thus, the course provides an introduction to evaluating and applying empirical evidence in schools. A course such as this serves the many needs of a program, especially when this course may be the only quantitative data course available to students. First, it provides a research-based application for students who will move into organizational leadership positions, providing an opportunity for them to learn new skills to evaluate and provide critical questions around decisions in schools, asking for evidence and research without just accepting "research says". Second, for students looking to deepen their skills and practice around statistics and data analytics, the course provides a grounding in the foundations for more complex data analysis. And third, the use of student's own data, provides a means to create buy-in from students, and provide a structured experience in applying evidence-based improvement cycle research to their organizations. A goal of the course is that by the end of a quantitative methods course, students are left with many more questions than they started with, as the research and analysis doors are opened (so to speak) on their work and the work of others. Given this goal, the question remains that beyond a single course, what can an education leadership graduate program do to help continue the conversation to help students deepen their practice, both around evaluating and applying quantitative and qualitative methods and research to their scholarship and practice? 
Beyond the quantitative methods course, the second strategy that I argue for here to build disciplined inquiry for school improvement capacity in education leadership graduate programs is the use of a research journal club (Bowers \& Murakami-Ramalho, 2010; Golde, 2007a, 2007b). Research journal clubs are well known in the broader humanities and natural sciences, and are a recently novel emerging strategy in education leadership graduate programs to bring faculty and students together in semi-formal settings to model the dialogue around critiquing and evaluating current research in education (Bowers \& Murakami-Ramalho, 2010). In a research journal club, faculty and students come together as peers, usually a few times a month, and take turns selecting a recent peer reviewed journal article for discussion that relates to the presenter's own work. The presenter then uses about 20 minutes to present the purpose, method and findings, and then the group spends the remaining hour discussing the article, from the methods, to the findings to the application, using a semi-structured protocol to encourage and model critical and inclusive dialogue. As has been shown in the journal club literature (Bowers \& MurakamiRamalho, 2010), this type of more informal approach beyond the classic methods courses, helps students unpack the complex arguments within articles and makes them more accessible, as the faculty model and include students within the conversation about how they see and understand the article. This semi-formal "signature pedagogy" (Bowers \& Murakami-Ramalho, 2010; Golde, 2007a) helps to shift students from a stance of trepidation when it comes to approaching research and methods, to a more inclusive and open stance of inquiry on how current research may apply (or not) to their schools, especially for scholarpractitioners. Additionally, this type of conversation can help to move faculty in a program beyond focusing on program delivery and help to build a professional community of research practice (Bowers \& Murakami-Ramalho, 2010; Pallas, 2001).

And finally, leading from these first two strategies, my third recommended strategy is to continue to build upon the recent emerging work from the university-district partnerships literature (Klostermann, Pareja, Hart, White, \& Huynh, 2015; Lochmiller, Chesnut, \& Stewart, 2015; Sanzo \& Scribner, 2015). In this work, graduate programs move from seeing individuals as the clients, to districts and schools as the clients, working in tandem to tap and train aspiring leaders as a means to address the needs of both the districts and the university, so that both sets of institutions can continually improve (Carnegie Project on the Education Doctorate, n.d.). Much of this work stems from the researcher-practitioner partnerships literature (Coburn, et al., 2013) as well as the recently emerging work on networked improvement communities in education (Bryk, et al., 2011; Bryk, Gomez, Grunow, \& LeMahieu, 2015). For the quantitative methods course in particular, a focus on improving the relationship between universities and districts can only help to serve to strengthen the types of issues discussed that may be not only relevant to the problems of practice of the districts, but also research-informed and focused on evidence-based improvement cycles for the districts, the university and their broader networked improvement community. As just one possible example, through a strong and specific university-district partnership, a central office administrator or superintendent could provide a focus for data action plan projects, in which the quantitative methods course could kick-off with a discussion by the district as to their current data, research, evaluation, and implementation needs, especially if the district has already gone through multiple rounds of a PDSA or Data Wise cycle (Bambrick-Santoyo, 2010; Boudett, et al., 2013; Bryk, et al., 2011). Additionally, providing co-instruction opportunities for district partner central office administrators who manage data issues to co-teach the quantitative methods courses with university faculty could provide useful insights and direction as students work to address important research and development issues in their districts through applying their learning through their assignments to the needs of the partner district.

\section{Beyond the First Course: Training for Four Distinct Quantitative Roles in Schools}

I conclude this discussion of training for quantitative methods for education leadership practitioner-scholars with the final point that there are at least four different types of data analytic leadership jobs in schools that graduate programs should take into account, beyond training for the general school administration. As noted by Bruno and Fox (1973), they discussed three main positions, and here I will add a fourth given current research on the data analytic needs of districts. I outline these four types and the training for each in Figure 1. First, is the "Practicing Administrator", who the traditional quantitative methods course is focused on training, such as aspiring superintendents and school administrators, for whom the quantitative methods course discussed throughout this paper should be designed. Second is the "Educational Quantitative Analyst". A person in this position is concerned with the day-today operational management data for the organization, such as assessment and test reporting to policymakers, enrollment trends and projections, addressing issues of accounting and cost-benefit analysis, searching for efficiencies in the system, analyzing data for bus routes and curriculum scheduling, and collecting data for personnel evaluations. The third Bruno and Fox (1973) quantitative position is the "Research Specialist". The person in this position is charged with conducting research on and with the organization, analyzing effectiveness, efficiency and instructional improvement. A contemporary example of this type of position may be researchers at organizations such as the University of Chicago Consortium on Chicago School Research (CCSR), in which a university-district partnership has developed over many years in which core research questions that are of interest to the Chicago Public Schools are addressed by researchers at CCSR through a mutually beneficial collaborative cooperation agreement (Roderick, Easton, \& Sebring, 2009). Through articulating these three different positions, Bruno and 


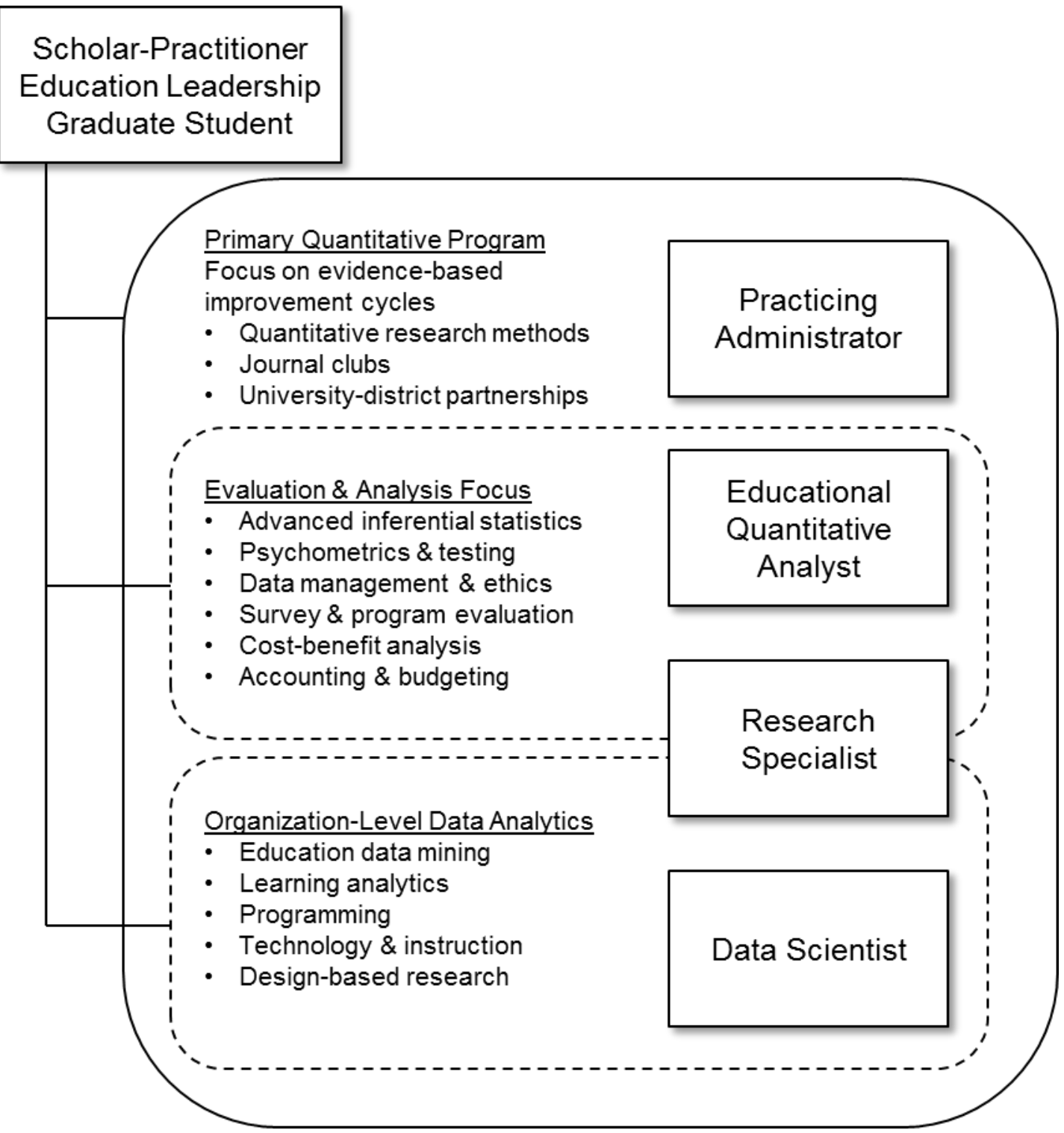

Figure 1: A Model for Quantitative Research Methods Training in Education Leadership Graduate Programs

Fox (1973) hoped to encourage programmatic diversity to help serve the needs of these different scholar-practitioners, starting first with the core quantitative methods course for all positions, but then providing focused cognates and sets of courses that could help train for the Educational Quantitative Analyst and the Research Specialist. Today, these additional courses might include advanced inferential statistics, psychometrics, survey and evaluation methods, data management and ethics, costbenefit analysis, and causal analysis. These types of courses may be included within a larger range of degree programs beyond the traditional education administration and leadership degrees, such as evaluation, measurement and policy, while still falling within the Bruno and Fox (1973) quantitative data district practitioner framework. As with Bruno and Fox (1973), I also content here that these types of data use roles by practitioners in districts are important to consider within a broader framing around program delivery for effective data practices in schools.

Furthermore, I argue here that there is a fourth type of quantitative education leadership practitioner-scholar position that has emerged over the last 40 years, Organization-Level Data Analytics. As exemplified in the work of programs such as Harvard's Strategic Data Project (SDP) (Hallgren, Pickens Jewell, Kamler, Hartog, \& Gothro, 2013; Wong, 2013), in which district and state data analysts are provided professional development and capacity building around applying data analytics to education data, data analytics in schooling organizations focuses on using the emerging research domains of big data and data science (U.S. Department of Education, 2012) to analyze the patterns in education data in new ways to 
create predictive analytics (R. S. Baker, 2013; Koedinger, D'Mello, McLaughlin, Pardos, \& Rosé, 2015), early warning systems (Bowers, 2014; Bowers, Sprott, \& Taff, 2013; Knowles, 2014), and data dashboard systems (Bowers, 2010a; Drake, 2015; Lacefield, Applegate, Zeller, \& Carpenter, 2012; Roderick, 2012) that help improve the information used for evidence-based improvement cycles (Bowers, et al., 2016; Feng, et al., 2016). This work differs from education data mining as it focuses on modeling the organization-level data, rather than moment-by-moment student cognition and learning. As an emerging field, courses that may be most beneficial for Organization-Level Data Analytics personnel include education data mining, data management, computer programming, humancomputer and user interaction design, learning management system software, statistics, and open source software use such as R (R Development Core Team, 2014). As recently noted by a special report by the US Department of Education on data analytics, one purpose of this work is to "make visible data that have heretofore gone unseen, unnoticed, and therefore unactionable" (p.ix) (U.S. Department of Education, 2012). Additionally, to link back to the main argument of this article in arguing for a central role of the quantitative methods work of practitioner-scholars to focus on translating data analysis into actionable information for evidence-based improvement cycles (Bowers, et al., 2016), I point to the following definition of a data scientist from Schutt and O’Neil (2013) which echoes well the point from Farmer (1970) that I used to start this article in which the point of the quantitative approach is to help to think about solving problems in new ways:

A data scientist is someone who knows how to extract meaning from and interpret data, which requires both tools and methods from statistics and machine learning, as well as being human... Once she gets the data into shape, a crucial part is exploratory data analysis, which combines visualization and data sense... She'll find patterns, build models, and algorithms... She may design experiments and is a critical part of data-driven decision making. She'll communicate with team members, engineers, and leadership in clear language and with data visualizations so that even if her colleagues are not immersed in the data themselves, they will understand the implications. p.16 (Schutt \& O'Neil, 2013).

Thus, for the future of quantitative methods courses in education leadership practitioner-scholar programs as disciplined inquiry for building school improvement capacity, the future is very bright. Education leadership graduate programs should work to address the needs of their practitioner-scholar students and schooling organizations through pivoting the traditional quantitative methods course to include a focus on evaluating and applying research and data analysis to evidence-based improvement cycles, including journal clubs as a means to enrich and deepen the professional community of research practice, and continue to build and study university-district partnerships as a means to further develop networked improvement communities through building capacity around data use and evidence-based improvement cycles. Additionally,

Bowers, A.J. (2017) graduate programs can position themselves well for the needs of their students through providing training around the four quantitative analytic educator positions of Practicing Administrator, Educational Quantitative Analyst, Research Specialist and District Data Scientist. For programs aimed to help inform the work of practitioner-scholars in schools and districts, pivoting the work around the quantitative research methods course in graduate programs of education leadership to address these types of issues could help to address the dual issues noted above of both the low ratings of usefulness by superintendents as well as the research critiques of such programs in the literature.

\section{Suggested Citation:}

Bowers, A.J. (2017) Quantitative Research Methods Training in Education Leadership and Administration Preparation Programs as Disciplined Inquiry for Building School Improvement Capacity. Journal of Research on Leadership Education, 12(1), p.72-96. http://doi.org/10.1177/1942775116659462

\section{REFERENCES:}

Anderson, E., \& Reynolds, A. (2015). The State of State Policies for Principal Preparation Program Approval and Candidate Licensure. Journal of Research on Leadership Education. doi: 10.1177/1942775115614292

Baker, B. D., Orr, M. T., \& Young, M. D. (2007). Academic Drift, Institutional Production, and Professional Distribution of Graduate Degrees in Educational Leadership. Educational Administration Quarterly, 43(3), 279-318. doi: $10.1177 / 0013161 \times 07303320$

Baker, R. S. (2013). Learning, Schooling, and Data Analytics. In M. Murphy, S. Redding \& J. Twyman (Eds.), Handbook on innovations in learning Philadelphia, PA: Center on Innovations in Learning, Temple University; Charlotte, NC: Information Age Publishing. Retrieved from http://www.centeril.org/.

Bambrick-Santoyo, P. (2010). Driven by Data: A Practical Guide to Improve Instruction. San Francisco, CA: JosseyBass.

Bernhardt, V. (2013). Data analysis for continuous school improvement (3 ed.). New York: Routledge.

Bird, J. J., Dunaway, D. M., Hancock, D. R., \& Wang, C. (2013). The Superintendent's Leadership Role in School Improvement: Relationships Between Authenticity and Best Practices. Leadership and Policy in Schools, 12(1), 77-99. doi: 10.1080/15700763.2013.766348

Boote, D. N., \& Beile, P. (2005). Scholars Before Researchers: On the Centrality of the Dissertation Literature Review in Research Preparation. Educational Researcher, 34(6), 3-15. doi: 10.3102/0013189x034006003

Boudett, K. P., City, E. A., \& Murnane, R. J. (2013). Data Wise: Revised and Expanded Edition: A Step-by-Step Guide to Using Assessment Results to Improve Teaching and Learning. Revised and Expanded Edition. Cambridge, MA: Harvard Education Press. 
Bowers, A. J. (2008). Promoting Excellence: Good to great, NYC's district 2, and the case of a high performing school district. Leadership and Policy in Schools, 7(2), 154-177.

Bowers, A. J. (2010a). Analyzing the longitudinal K-12 grading histories of entire cohorts of students: Grades, data driven decision making, dropping out and hierarchical cluster analysis. Practical Assessment Research and Evaluation, 15(7), 1-18.

Bowers, A. J. (2010b). Toward Addressing the Issues of Site Selection in District Effectiveness Research: A Two-Level Hierarchical Linear Growth Model. Educational Administration Quarterly, 46(3), 395-425. doi: 10.1177/0013161X10375271

Bowers, A. J. (2014). Student Risk Factors. In D. J. Brewer \& L. O. Picus (Eds.), Encyclopedia of Education Economics and Finance. Thousand Oaks, CA: Sage Publications.

Bowers, A. J. (2015). Site Selection in School District Research: A Measure of Effectiveness Using Hierarchical Longitudinal Growth Models of Performance. School Leadership \& Management, 35(1), 39-61. doi: $10.1080 / 13632434.2014 .962500$

Bowers, A. J., \& Chen, J. (2015). Ask and Ye Shall Receive? Automated Text Mining of Michigan Capital Facility Finance Bond Election Proposals to Identify which Topics are Associated with Bond Passage and Voter Turnout. Journal of Education Finance, 41(2), 164-196.

Bowers, A. J., Krumm, A. E., Feng, M., \& Podkul, T. (2016). Building a Data Analytics Partnership to Inform School Leadership Evidence-Based Improvement Cycles. Paper presented at the Annual meeting of the American Educational Research Association, Washington, DC.

Bowers, A. J., \& Lee, J. (2013). Carried or Defeated? Examining the Factors Associated With Passing School District Bond Elections in Texas, 1997-2009. Educational Administration Quarterly, 49(5), 732-767. doi: 10.1177/0013161x13486278

Bowers, A. J., \& Murakami-Ramalho, E. (2010). The Research Journal Club: Pedagogy of Research in the Preparation of Students in Educational Leadership. Journal of Research on Leadership Education, 5(10), 335-356. doi: 10.1177/194277511000501001

Bowers, A. J., Shoho, A. R., \& Barnett, B. G. (2014). Considering the Use of Data by School Leaders for Decision Making. In A. J. Bowers, A. R. Shoho \& B. G. Barnett (Eds.), Using Data in Schools to Inform Leadership and Decision Making (pp. 1-16). Charlotte, NC: Information Age Publishing.

Bowers, A. J., Sprott, R., \& Taff, S. (2013). Do we know who will drop out? A review of the predictors of dropping out of high school: Precision, sensitivity and specificity. The High School Journal, 96(2), 77-100.

Brocato, K., Willis, C., \& Dechert, K. (2014). Longitudinal Data Use: Ideas for District, Building, and Classroom Leaders In A. J. Bowers, A. R. Shoho \& B. G. Barnett (Eds.), Using Data in Schools to Inform Leadership and Decision Making (pp. 97-120). Charlotte, NC: Information Age Publishing.

Brooks, J. S. (2012). Black School White School: Racism and Educational (Mis) Leadership. New York, NY: Teachers College Press.
Bruno, J. E., \& Fox, J. N. (1973). Quantitative Analysis in Educational Administrator Preparation Programs. Columbus, Ohio: The ERIC Clearinghouse on Educational Management, University Council for Educational Administration.

Bryk, A. S., Gomez, L., \& Grunow, A. (2011). Getting Ideas into Action: Building Networked Improvement Communities in Education. In M. T. Hallinan (Ed.), Frontiers in Sociology of Education (Vol. 1, pp. 127-162): Springer Netherlands.

Bryk, A. S., Gomez, L. M., Grunow, A., \& LeMahieu, P. G. (2015). Learning to Improve: How America's Schools Can Get Better at Getting Better Cambridge, MA: Harvard Education Press.

Carnegie Project on the Education Doctorate. (n.d.). The Carnegie Project on the Education Doctorate, from http://cpedinitiative.org/

Carter, D. S. G., Glass, T. E., \& Hord, S. M. (1993). Selecting, preparing and developing the school district superintendent. London: RoutledgeFalmer.

Cho, V., \& Wayman, J. C. (2015). Districts' Efforts for Data Use and Computer Data Systems: The Role of Sensemaking in System Use and Implementation. Teachers College Record, 116(2), 1-45.

Coburn, C. E., Penuel, W. R., \& Geil, K. E. (2013). ResearchPractice Partnerships: A Strategy for Leveraging Research for Educational Improvement in School Districts. New York, NY: William T. Grant Foundation.

Cohen, J., Cohen, P., West, S. G., \& Aiken, L. S. (2003). Applied multiple regression/correlation analysis for the behavioral sciences (Third ed.). New York: Taylor and Francis.

Corcoran, C., Peck, C. M., \& Reitzug, U. C. (2013). Exiting school improvement sanctions: Accountability, morale, and the successful school turnaround principal. In B. G. Barnett, A. R. Shoho \& A. J. Bowers (Eds.), School and district leadership in an era of accountability (pp. 63-83). Charlotte, NC: Information Age Publishing Inc.

Cosner, S. (2014). Strengthening Collaborative Practices in Schools: The Need to Cultivate Development Perspectives and Diagnostic Approaches. In A. J. Bowers, A. R. Shoho \& B. G. Barnett (Eds.), Using Data in Schools to Inform Leadership and Decision Making. Charlotte, NC: Information Age Publishing.

Cunningham, L. L., \& Nystrand, R. O. (1969). Toward Greater Relevance in Preparation Programs for Urban School Administrators. Educational Administration Quarterly, 5(1), 6-23. doi: 10.1177/0013131x6900500102

Davis, B. W., Gooden, M. A., \& Bowers, A. J. (2015). Traversing Transcultural Spaces: An Event History Analysis of Teachers' Pathways to the Principalship. Paper presented at the Annual meeting of the University Council for Educational Administration (UCEA), San Diego, CA.

de Levie, R. (2012). Advanced Excel for scientific data analysis (3rd ed.). New York: Oxford University Press.

DeAngelis, K. J., \& Ayers, S. (2009). What does the average really mean? Making sense of statistics. School Business Affairs, 75(1), 18-20. 
Drago-Severson, E., \& Blum-DeStefano, J. (2013). A new approach for new demands: the promise of learning-oriented school leadership. International Journal of Leadership in Education, 16(1), 1-33. doi: 10.1080/13603124.2012.741265

Drake, T. A. (2015). Exploring the Factors and Conditions Associated with Principals' Use of District Data Systems. Paper presented at the Annual meeting of the American Educational Research Association, Chicago, IL.

Farley-Ripple, E. N., \& Cho, V. (2014). Depth of Use: How District Decision-makers Did and Did Not Engage with Evidence. In A. J. Bowers, A. R. Shoho \& B. G. Barnett (Eds.), Using Data in Schools to Inform Leadership and Decision Making (pp. 229-252). Charlotte, NIC: Information Age Publishing.

Farmer, J. (1970). Why Planning, Programming, Budgeting Systems for Higher Education? Boise, ID: Western Interstate Commission for Higher Education.

Feng, M., Krumm, A. E., Bowers, A. J., \& Podkul, T. (2016). Elaborating Data Intensive Research Methods through Researcher-Practitioner Partnerships. Paper presented at the International Learning Analytics and Knowledge (LAK) Conference, Edinburgh, UK.

Fusarelli, L. D. (2008). Flying (partially) blind: School leaders' use of research in decisionmaking. In F. M. Hess (Ed.), When research matters: How scholarship influences education policy (pp. 177-196). Cambridge, Mass: Harvard Education Press.

Gelman, A., \& Loken, E. (2013). The garden of forking paths: Why multiple comparisons can be a problem, even when there is no "fishing expedition" or "p-hacking" and the research hypothesis was posited ahead of time, from http://www.stat.columbia.edu/ gelman/research/unpublished/ p_hacking.pdf

Goff, P., \& Finch, M. (2015). Challenges and Opportunities for Education Leadership Scholarship: A Methodological Critique. In A. J. Bowers, A. R. Shoho \& B. G. Barnett (Eds.), Challenges and Opportunities of Educational Leadership Research and Practice: The State of the Field and Its Multiple Futures (Vol. 6, pp. 119-146). Charlotte, NC: Information Age Publishing.

Golde, C. M. (2007a). Signature pedagogies in doctoral education: Are they adaptable for the preparation of education researchers? Educational Researcher, 36(6), 344351.

Golde, C. M. (2007b). Teaching students to ask good research questions. Paper presented at the Annual Meeting of the Association for the Study of Higher Education, Louisville, KY.

Goldring, E., \& Schuermann, P. (2009). The changing context of K-12 education administration: Consequences for Ed.D. program design and delivery. Peabody Journal of Education, 84(1), 9-43.

Grogan, M., \& Andrews, R. (2002). Defining Preparation and Professional Development for the Future. Educational Administration Quarterly, 38(2), 233-256. doi: 10.1177/0013161x02382007

Guthrie, J. (2009). The Case for a Modern Doctor of Education Degree (Ed.D.): Multipurpose Education Doctorates No

Bowers, A.J. (2017)
Longer Appropriate. Peabody Journal of Education, 84(1), 38.

Hackmann, D. G., \& McCarthy, M. M. (2011). At a Crossroads: The Educational Leadership Professoriate in the 21st Century. Charlotte, NC: Information Age Publishing.

Hallgren, K., Pickens Jewell, C., Kamler, C., Hartog, J., \& Gothro, A. (2013). Strategic data project and education pioneers year 1 report: Laying the groundwork for datadriven decision making. Princenton, NJ: Mathematica Policy Research.

Hallinger, P., \& Heck, R. H. (2011). Conceptual and methodological issues in studying school leadership effects as a reciprocal process. School Effectiveness and School Improvement, 22(2), 149-173. doi: $10.1080 / 09243453.2011 .565777$

Halverson, R. (2010). School formative feedback systems. Peabody Journal of Education, 85(2), 130-146. doi: 10.1080/0161956100368527

Herr, K. G., \& Anderson, G. L. (2015). The Action Research Dissertation: A guide for students and faculty. Thousand Oaks, CA: SAGE Publications.

Hess, F. M., \& Kelly, A. P. (2005). Textbook leadership? An analysis of leading books used in principal preparation. Cambridge, MA: The Program on Education Policy and Governance.

Hills, J. (1965). Social Science, Ideology, and the Professor of Educational Administration. Educational Administration Quarterly, 1(3), 23-39. doi: 10.1177/0013161x6500100303

Honig, M. I. (2003). Building Policy from Practice: District Central Office Administrators' Roles and Capacity for Implementing Collaborative Education Policy. Educational Administration Quarterly, 39(3), 292-338. doi: 10.1177/0013161x03253414

Honig, M. I. (2008). District Central Offices as Learning Organizations: How Sociocultural and Organizational Learning Theories Elaborate District Central Office Administrators' Participation in Teaching and Learning Improvement Efforts. American Journal of Education, 114(4), 627-664. doi: 10.1086/589317

Honig, M. I. (2009). No small thing: School district central office bureaucracies and the implementation of new small autonomous school initiatives. American Educational Research Journal, 46(2), 387-422.

Honig, M. I. (2012). District Central Office Leadership as Teaching: How Central Office Administrators Support Principals' Development as Instructional Leaders. Educational Administration Quarterly, 48(4), 733-774. doi: $10.1177 / 0013161 \times 12443258$

Horsford, S. D. (2010). Mixed Feelings About Mixed Schools: Superintendents on the Complex Legacy of School Desegregation. Educational Administration Quarterly, 46(3), 287-321. doi: 10.1177/0013161x10365825

Huff, D., \& Geis, I. (1954). How to lie with statistics. New York: W.W. Norton.

Jacobs, J., Gregory, A., Hoppey, D., \& Yendol-Hoppey, D. (2009). Data Literacy: Understanding Teachers' Data Use in a Context of Accountability and Response to Intervention. 
Action in Teacher Education, 31(3), 41-55. doi:

10.1080/01626620.2009.10463527

Klostermann, B. K., Pareja, A. S., Hart, H., White, B. R., \& Huynh, M. H. (2015). Restructuring Principal Preparation in Illinois: Perspectives on Implementation Successes, Challenges, and Future Outlook. Edwardsville, IL: Illinois Education Research Council.

Knezevich, S. J. (1971). The American School Superintnedent. An AASA Research Study. Washington, DC: American Association of School Administrators.

Knowles, J. E. (2014). Of Needles and Haystacks: Building an Accurate Statewide Dropout Early Warning System in Wisconsin. Madison, WI: Wisconsin Department of Public Instruction.

Koedinger, K. R., D'Mello, S., McLaughlin, E. A., Pardos, Z. A., \& Rosé, C. P. (2015). Data mining and education. Wiley Interdisciplinary Reviews: Cognitive Science, n/a-n/a. doi: 10.1002/wcs. 1350

Kowalski, T. J., McCord, R. S., Peterson, G. J., Young, P. I., \& Ellerson, N. M. (2011). The American School Superintendent : 2010 Decennial Study. Lanham, Md: R\&L Education.

Lacefield, W., Applegate, B., Zeller, P. J., \& Carpenter, S. (2012). Tracking students' academic progress in data rich but analytically poor environments. Paper presented at the Annual meeting of the American Educational Research Association, Vancouver, BC.

https://www.google.com/url?sa=t\&rct=j\&q=\&esrc=s\&source $=$ web \&cd=1\&ved $=0 \mathrm{CCkQFjAA} \& u r l=\mathrm{http} \% 3 \mathrm{~A} \% 2 \mathrm{~F} \% 2 \mathrm{Fww}$ w.rockyview.ab.ca\%2Fhome\%2Fprofessionallearning\%2Fresearch\%2Fresearch \%2F2012-lacefield-poorenvironments\%2Fat download\%2Ffile\&ei=vig3UtrtFO2y4A PkxYGwCg\&usg=AFQjCNHfmFIZqkPBrUq9cuyIVzE73a9 ypQ\&bvm=bv.52164340,d.dmg\&cad=rja

Leithwood, K. (2013). Concluding synthesis and commentary. In B. G. Barnett, A. R. Shoho \& A. J. Bowers (Eds.), School and district leadership in an era of accountability (pp. 255269). Charlotte, NC: Information Age Publishing Inc.

Levine, A. (2005). Educating school leaders. New York: Education Schools Project.

Lochmiller, C. R., Chesnut, C. E., \& Stewart, M. S. (2015). Preparing leaders in an era of school turnarounds: The promise of university/district partnerships as a lever for program improvement. In A. J. Bowers, A. R. Shoho \& B. G. Barnett (Eds.), Challenges and Opportunities of Educational Leadership Research and Practice: The State of the Field and Its Multiple Futures (Vol. 6, pp. 199-223). Charlotte, NC: Information Age Publishing.

Mandinach, E. B., Friedman, J. M., \& Gummer, E. S. (2015). How Can Schools of Education Help to Build Educators' Capacity to Use Data? A Systemic View of the Issue. Teachers College Record, 117(4), 1-50.

Mandinach, E. B., \& Gummer, E. S. (2013). A Systemic View of Implementing Data Literacy in Educator Preparation. Educational Researcher, 42(1), 30-37. doi: 10.3102/0013189x12459803

Mandinach, E. B., \& Gummer, E. S. (2016). Data Literacy for Educators: Making It Count in Teacher Preparation and Practice New York: Teachers College Press.
Marsh, J. A. (2012). Interventions Promoting Educators' Use of Data: Research Insights and Gaps. Teachers College Record, 114(11), 1-48.

Marsh, J. A., Bertrand, M., \& Huguet, A. (2015). Using Data to Alter Instructional Practice: The Mediating Role of Coaches and Professional Learning Communities. Teachers College Record, 114(4), 1-40.

McCarthy, M. M., \& Forsyth, P. B. (2009). An Historical Review of Research and Development Activities Pertaining to the Preparation of School Leaders. In M. D. Young, G. M. Crow, J. Murphy \& R. T. Ogawa (Eds.), Handbook of Research on the Education of School Leaders. New York: Routledge.

McEwan, E. K., \& McEwan, P. J. (2003). Making Sense of Research: What's Good, What's Not, and How To Tell the Difference. Thousand Oaks, CA: Corwin Press.

Militello, M., Gajda, R., \& Bowers, A. J. (2009). The Role of Accountability Policies and Alternative Certification on Principals' Perceptions of Leadership Preparation. Journal of Research on Leadership Education, 4(3), 30-66. doi: 10.1177/194277510900400301

Oplatka, I. (2009). The field of educational administration: A historical overview of scholarly attempts to recognize epistemological identities, meanings and boundaries from the 1960s onwards. Journal of Educational Administration, 47(1), 8-35. doi: 10.1108/09578230910928061

Osguthorpe, R., \& Wong, M. (1993). The Ph.D. versus the Ed.D.: Time for a decision. Innovative higher education, 18(1), 47-63. doi: 10.1007/bf01742197

Pallas, A. M. (2001). Preparing education doctoral students for epistemological diversity. Educational Researcher, 30(5), 611.

Perry, J. A. (2012). To Ed.D. or not to Ed.D.? Phi Delta Kappan, 94(1), 41-44.

Piety, P. J. (2013). Assessing the educational data movement. New York, NY: Teachers College Press.

Popham, W. J. (2009). Assessment Literacy for Teachers: Faddish or Fundamental? Theory Into Practice, 48(1), 4-11. doi: 10.1080/00405840802577536

Popham, W. J. (2010). Everything school leaders need to know about assessment. Thousand Oaks, CA: Corwin.

R Development Core Team. (2014). R: A language and environment for statistical computing. Vienna, Austria: R Foundation for Statistical Computing. Retrieved from http://www.R-project.org

Reyes, P., \& Wagstaff, L. (2005). How does leadership promote successful teaching and learning for diverse students. In W. A. Firestone \& C. Riehl (Eds.), A new agenda for research in educational leadership (pp. 101-118). New York: Teachers College Press.

Riehl, C. J. (2015). Mostly Unpunctuated Disequilibrium: A Commentary on New Directions in Research and Practice in Education Leadership. In A. J. Bowers, A. R. Shoho \& B. G. Barnett (Eds.), Challenges and Opportunities of Educational Leadership Research and Practice: The State of the Field and Its Multiple Futures (Vol. 6, pp. 225-248). Charlotte, NC: Information Age Publishing. 
Roderick, M. (2012). Drowning in Data but Thirsty for Analysis. Teachers College Record, 114(11).

Roderick, M., Easton, J. Q., \& Sebring, P. B. (2009). The Consortium on Chicago School Research (CCSR): A new model for the role of research in supporting urban school reform. Chicago: The Consortium on Chicago School Research.

Sanzo, K. L., \& Scribner, J. P. (2015). Leadership Preparation in Small and Mid-Sized Urban School Districts Leading Small and Mid-Sized Urban School Districts (pp. 21-39).

Saunders, W. M. (1999). Improving Literacy Achievement for English Learners in Transitional Bilingual Programs. Educational Research and Evaluation, 5(4), 345-381. doi: 10.1076/edre.5.4.345.6936

Schildkamp, K., \& Poortman, C. (2015). Factors Influencing the Functioning of Data Teams. Teachers College Record, 117(4), 1-42.

Schildkamp, K., Poortman, C. L., \& Handelzalts, A. (2015). Data teams for school improvement. School Effectiveness and School Improvement, 1-27. doi: 10.1080/09243453.2015.1056192

Schildkamp, K., Poortman, C. L., \& Handelzalts, A. (2016). Data teams for school improvement. School Effectiveness and School Improvement, 27(2), 228-254. doi: 10.1080/09243453.2015.1056192

Schreiber, J., \& Asner-Self, K. (2011). Educational Research: The interrelationship of questions, sampling, design and analysis. Hoboken, NJ: Wiley.

Schutt, R., \& O'Neil, C. (2013). Doing Data Science: Straight Talk from the Frontline. Cambridge, MA: O'Reilly.

Shulman, L. S., Golde, C. M., Bueschel, A. C., \& Garabedian, K. J. (2006). Reclaiming Education's Doctorates: A Critique and a Proposal. Educational Researcher, 35(3), 25-32. doi: 10.3102/0013189x035003025

Smrekar, C., \& McGraner, K. (2009). From Curricular Alignment to the Culminating Project: The Peabody College Ed.D. Capstone. Peabody Journal of Education, 84(1), 4860. doi: 10.1080/01619560802679641

Thornton, B., \& Perreault, G. (2002). Becoming a Data-Based Leader: An Introduction. NASSP Bulletin, 86(630), 86-96. doi: 10.1177/019263650208663009

Townsend, B. K. (2002). Rethinking the Ed.D., or What's in a Name? Paper presented at the Annual Meeting of the Association for the Study of Higher Education, Sacramento, CA. http://eric.ed.gov/?id=ED471507

Tufte, E. R. (2001). The visual display of quantitative information (2nd ed.). Cheshire, CT: Graphics Press.

U.S. Department of Education. (2012). Enhancing Teaching and Learning Through Educational Data Mining and Learning Analytics: An Issue Brief. Washington, DC: U.S. Department of Education, Office of Educational Technology.

US Department of Education. (n.d.). What Works Clearninghouse, from http://ies.ed.gov/ncee/wwc/

Wallace Foundation. (2013). Districts Matter: Cultivating the principals urban schools need. New York, NY.

Wang, Y., \& Bowers, A. J. (2016). Mapping the Field of Educational Administration Research: A Journal Citation Network Analysis of the Discipline. Journal of Educational

Bowers, A.J. (2017)
Administration, 54(3), 242-269. doi: 10.1108/JEA-02-20150013

Wang, Y., Bowers, A. J., \& Fikis, D. J. (2015). An Automated Text Data Mining Analysis of All EAQ Articles from 1965 to 2014. Paper presented at the Annual meeting of the University Council for Educational Administration (UCEA), San Diego, CA.

Wayman, J. C., Cho, V., Jimerson, J. B., \& Snodgrass Rangel, V. W. (2015). A Look into the Workings of Data Use in a Mid-Sized District. In I. E. Sutherland, K. L. Sanzo \& J. P. Scribner (Eds.), Leading Small and Mid-Sized Urban School Districts (Vol. 22, pp. 241-275): Emerald.

Wayman, J. C., \& Stringfield, S. (2006). Data use for school improvement: School practices and research perspectives. American Journal of Education, 112(4), 463-468.

Wong, K. K. (2013). Governing with data: The role of independent review panels in urban districtsThe infrastructure of accountability: Data use and the transformation of American education (pp. 95-111). Cambridge, Mass: Harvard Education Press.

WWC. (2006). WWC Intervention Report: Instructional conversations and literature logs. Washington, DC: What Works Clearinghouse, Institute of Education Sciences, US. Department of Education. 